Rev. Geol. Amér. Central, 18: 91-94, 1995

\title{
STRATIGRAPHY AND SEDIMENTOLOGY IN WESTERN NICARAGUA
}

\author{
Risto A. Kumpulainen \\ Department of Geology and Geochemistry, Stockholm University, S-106 91 \\ Stockholm, Sweden. Fax No. +468 345808.
}

The uppermost Cretaceous to Tertiary volcanisedimentary succesion along the Pacific coast of Nicaragua is by tradition divided into five "formations" based on lithostratigraphy, petrography and paleontology. These formations form a westdipping sequence and are exposed in belts semiparallel to the coast, the oldest formation being exposed in the core of the Rivas anticline (Fig. 1). The succession extends to the southeast into Costa Rica and Panama. Recent work in those areas has been summarized by Seyfried et al. (1991). A selection of stratigraphic columns for SW Nicaragua by various authors evidencing their different interpretation of the geological information is shown in Fig. 2.

The sedimentary succession of western Nicaragua rests on a Jurassic to mid Cretaceous ophiolitic basement (Nicoya Complex of northern Costa Rica). The two lowermost stratigraphic units ("Rivas fm" and "Brito fm", totaling c. 5,350 m) display a coarsening upwards cyclicity (three firstorder cycles) and consist of basin plain and deep water fan deposits. Supply of clastic material was to the Rivas unit from the south while the Brito unit also received some material from the east (Astorga, 1988).

An angular unconformity was inferred by Kuang (1971) on top of the Brito unit leading to subsequent inference, by several authors, of a period of uplift and erosion. Recent data on secondary minerals (Levi et al., 1995) lend support to an inferred unconformity. However, cleaning of the type locality of the unconformity revealed (pre- sent study) an erosional scarp formed by a submarine, coarse-clastic mass-flow cutting subjacent deposits, while turbidite (back ground) sedimentation continued rigth through the "unconformity" into the overlying "Masachapa fm". A change in the character of sedimentation would have been probable, if the unconformity was there. The "Masachapa fm" (c. 1,500 m) constitutes a coarsening-upwards sequence of turbidites with occasional debrites and goes through a diffuse transition into shallow-water sedimentation of the "El Fraile fm" (c. 100-2,700 m), the latter formation being described by Kolb (1990). Work on microfossils (coccoliths, pollen and spores) is in progress in order to clarify the stratigraphy from the top of the Brito unit into the El Fraile unit.

The gradual late Cretaceous to late Miocene shallowing-up of sedimentation in this fore-arc basin is substantiated further by palaeobathymetric studies, based essentially on benthic foraminifera collected from cuttings from drill holes, Corvina 1 and 2, from the present Nicaraguan shelf (Pickett, In Oceanic Exploration Co., 1975) some $35 \mathrm{~km}$ outside the coast line (Fig. 1). These studies suggest that abyssal depths prevailed in Eocene-Oligocene ("Brito" to "Masachapa") times, upper bathyal environments were probable in the early Miocene (upper part of the "Masachapa"), while a neritic environment was reached in the middle Middle Miocene ("El Fraile") and prevailed into Pliocene (El Salto). 


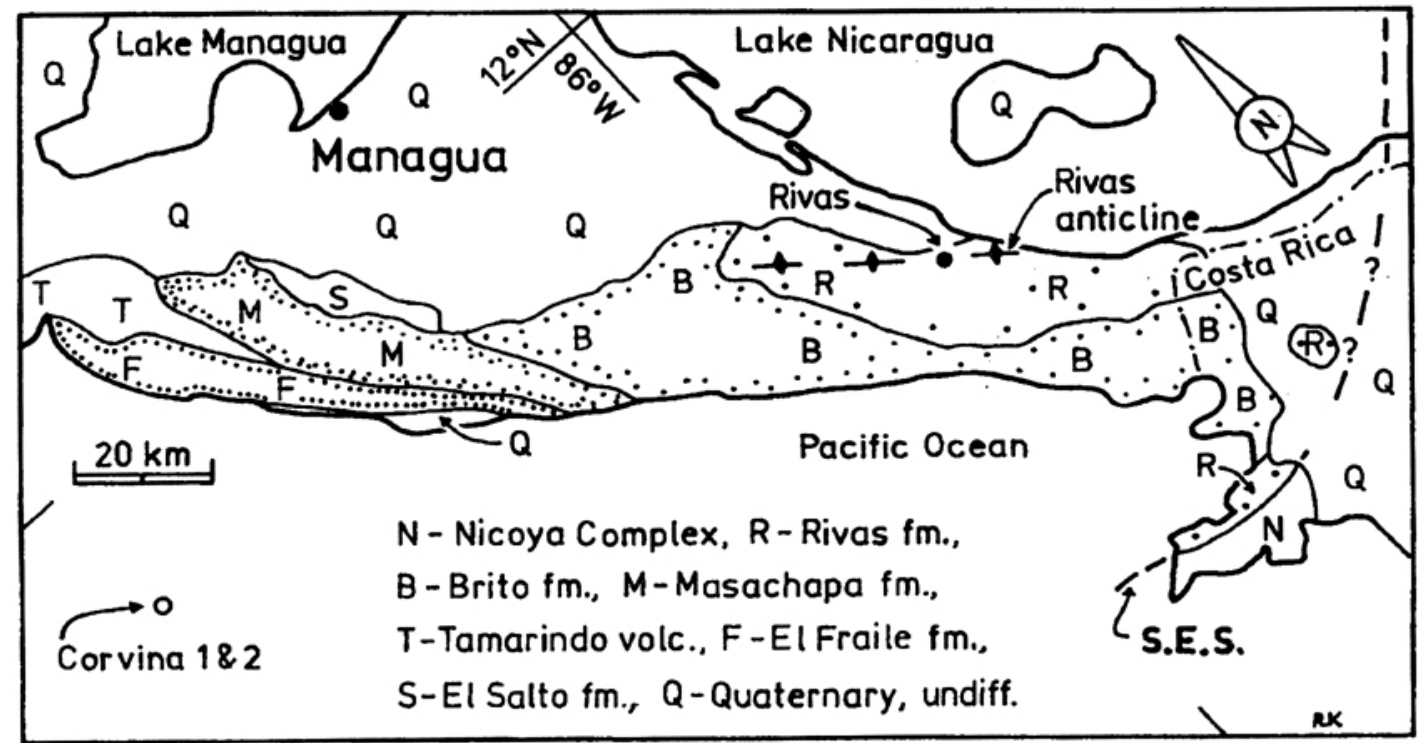

Fig. 1. Generalized geological map, simplified from Parsons Corporation (1972). Santa Elena Suture (S.E.S.) on the Nicoya Peninsula is from Escalante (1991).

Structural analysis on the sedimentary rocks on the Pacific Coast of western Nicaragua carried out by Cruden (1989) and Weinberg (1990) detect the first period of deformation, i.e. folding along NW-SE axis, (possible) thrusting, uplift, oceanward tilting and erosion of the sequence to take place in the late Miocene.

The next stratigraphic unit, the El Salto formation (c. $30 \mathrm{~m}$ ), is underlain in its area of development by the "Masachapa fm". The El Salto formation represents a period of quiescence allowing the deposition of shallow-water bioclastic limestones, local oyster reefs, marls and some interfingering volcaniclastic beds on this late MiocenePliocene unconformity. These volcaniclastic beds mark the initiation (Early Pleistocene) of volcanic activity whithin the present volcanic arc, which produced the volcaniclastic succession of the overlying Las Sierras group (c. $800 \mathrm{~m}$ ).

The development of the late Cretaceous to Tertiary fore-arc basin of southwestern Nicaragua outlined above appears to be different to that of the corresponding basins of Costa Rica (Seyfried et al., 1991). In the latter area the structural and sedimentary development is more complex suggesting that the Costarican section was exposed to periods of compression and uplift probably due to not only subduction of the Cocos Plate below Central America but also due to the relative movements of South America. Probable strike-slip movements along the Hess Escarpment (see Seyfried et al., 1991) and other related faults allowed western Nicaragua to escape from deformation, emergence, and erosion until the late Miocene.

\section{ACKNOWLEDGEMENTS}

This project was initiated on suggestion by Dr. M. Darce (INMINE). Director L. Lanza (INE) allowed access to some unpublished reports and the Troëng-Unnes family provided logistic help. An earlier version of this note was commented by Dr. B. Levi and Dr. J. O. Nyström. This note is published by the permission of the Geological Society of Sweden and was prepared for a meeting on "Crustal evolution and metallogenesis of Nicaragua and adjacent areas" held in Stockholm, December 1990 . The study was financed by the Swedish Agency for Research Co-operation with developing Countries (SAREC). All this help is kindly acknowledged. 


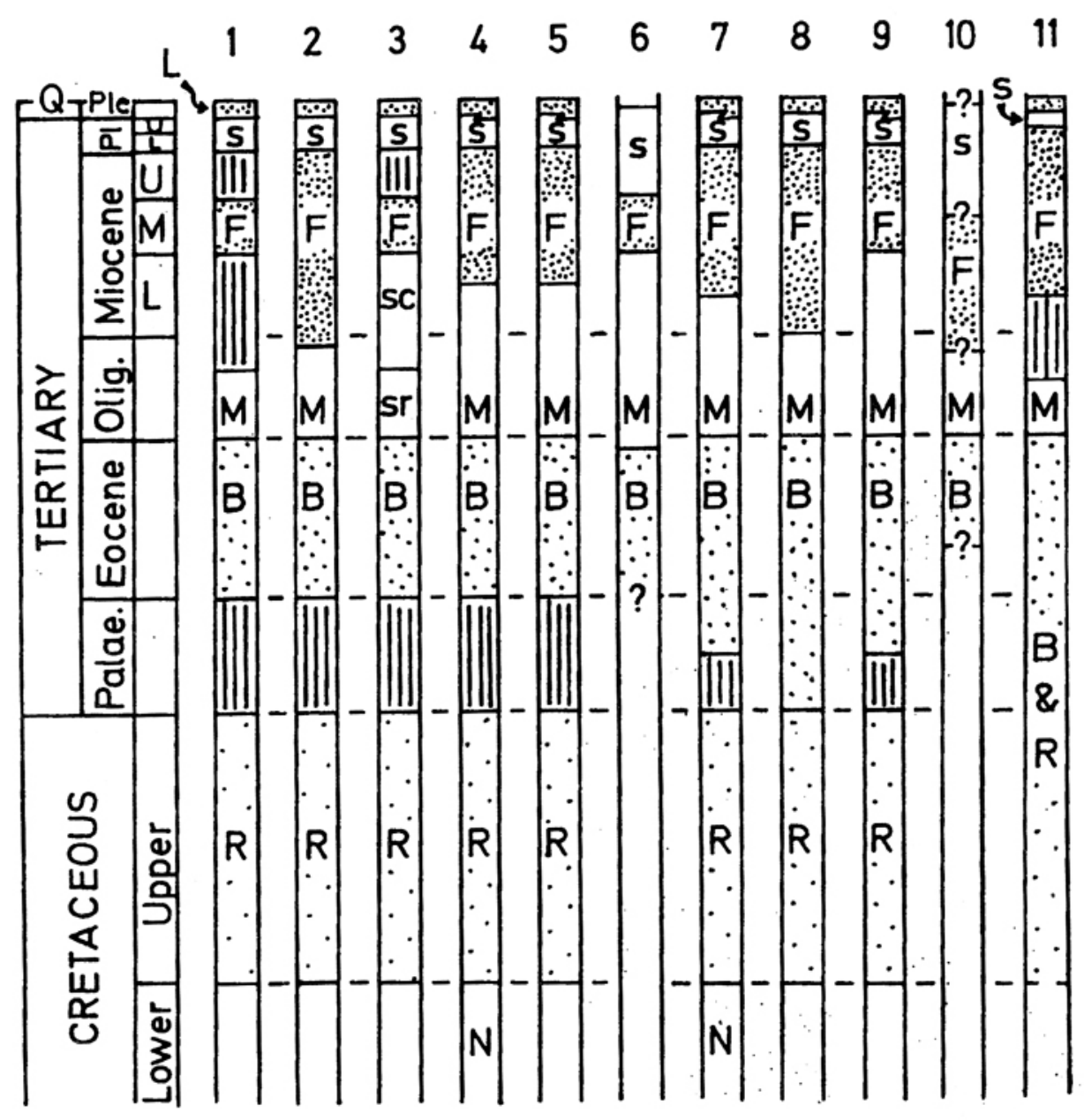

Fig. 2. A summary of opinions placing the various volcaniclastic formations of the Pacific Coast of Nicaragua in a time scale. 1 . Wilson (1942), 2 - Zoppis Bracci \& del Giudice (1958), 3 - Karim \& Chillingar (1964), 4 - Kuang (1971), 5 - Parsons Co. (1972), 6 - El Paso (Corvina 2) In Zezula (1980, Fig. 3), 7 - CanOceanic In Petronic (1986), 8 - Compañía Olade (1983), 9 - Petronic (1986), 10 - Steinberg (1989) (Corvina 2), 11- Kolb (1990). Formation symbols: s - El Salto formation, sc - San Cayetano formation, sr San Rafael formation; the other symbols are as on Fig. 1. Vertical hatching corresponds to stratigraphic gaps.

\section{REFERENCES}

ASTORGA, A., 1988: Geodinámica de las cuencas del Cretácico Superior-Paleógeno de la región "forarc" del Sur de Nicaragua de Costa Rica. Rev. geol. América Central, 9: 1-40.

Compañía Olade (J. Méndez \& M. Jones E.), 1983: Potencial Hidrocarbúfero de Nicaragua Grupo III de evaluación (PDVSA/MEM). Unpublished report (INE).
CRUDEN, A. R., 1989: The structure of SouthWest Nicaragua: a preliminary assesment. SGAB/INMINE/SAREC report URAP 89001, 26 pp. SGAB. Luleå, Sweden.

ESCALANTE, G., 1991: The geology of southern Central America and western Colombia. - In: Dengo, G. \& Case, J. E. (eds.): The Caribbean Region. Geological Society of America. The geology of North America, vol. H: 201-230. 
KARIM, M. \& CHILLINGAR, G.V., 1964: Nicaragua's coast has oil possibilities. World Oil, September 1964: 117-123.

KOLB, W., 1990: Die Neogene Schelf-sedimentazion in Südwest-Nicaragua: Ablagerungssequenzen und paläogeographische Szenarien. - $161 \mathrm{pp}$. Institut für Geologie und Paläontologie der Universität Stuttgart (Dr. rer. nat. thesis).

KUANG, J., 1971: Estudio geológico del Pacífico de Nicaragua. - Catastro e Inventario de Recursos Naturales, Informe geológico, 3, 101 pp. División de Geología. Managua.

LEVI, B., KUMPULAINEN, R. \& DARCE, M., (1995): Diagenesis in the volcaniclastic sequences of western Nicaragua: mineralogical breaks and tectonic implications. - Rev. geol. América Central, 18.

OCEANIC Exploration Co., 1975: Exploration Report Pacific Offshore. - Unpublished report (INE). Managua.

PARSONS Corporation 1972: The Geology of western Nicaragua. - Nicaragua Tax Improvement and Natural Resources Inventory Project, Final Technical Report. Vol. IV, 220 pp. Managua.

PETRONIC, 1986: Geología y potencial petrolífero y gasífero de Nicaragua. - Tomo I. 243 pp., unpublished report (INE). Managua.
SEYFRIED, H., AMMAN, M., ASTORGA, A., CALVO, C., KOLB, W., SCHMIDT, H., \& WINSEMANN, J., 1991: Anatomy of an evolving island arc: tectonic and eustatic control in the south Central America fore-arc area .- Internat. Ass. Sedimentologists, Spec. Publ. 12: 217-240.

STEINBERG, E., !989: Asesoría en Micropaleontología y bioestratigrafía prestada a INEplanificación. Informes de labores realizadas y resultados preliminares.- Proyecto SGAB/INMINE/SAREC-Nicaragua. - Unpublished report. 20 pp. UNAN/CIGEO archives. Managua.

WEINBERG, R.F., 1990: The Neogene structural development of western Nicaragua.SGAB/UNAN/SAREC report URAP 90002. 40 pp. SGAB. Luleå. Sweden.

WILSON, T.C., 1942: Summary report geology of Pacific coast area - Nicaragua. - Unpublished report. 27 pp. Managua.

ZEZULA, G., 1980: Evaluation of hydrocarbon possibilities in the Pacific Region of Nicaragua. - Instituto Nicaragüense de Minas Hidrocarburos, División de Hidrocarburos. Unpublished report. $71 \mathrm{pp}$. (INE). Managua.

Zoppis Bracci, L. \& del Giudice, D., 1958: Geología de la costa del Pacífico de Nicaragua. - Boletín del Servicio Geológico Nacional, Nicaragua 1: 29-34. 